Original paper

\title{
Tsunami Impact Assessment and Vulnerability Index Development using Computable General Equilibrium (CGE) Model and Geographic Information System (GIS) - A Study on Mie Prefecture, Japan
}

\author{
Hajime Tanaka $^{1}$, Nagisa Shiiba ${ }^{2}$ and Michael C. Huang ${ }^{1 *}$
}

Received: 15/10/2020 / Accepted: 12/04/2021 / Published online: 23/09/2021

\begin{abstract}
Japan is highly prone to multiple natural hazards, such as typhoons, earthquakes, and tsunamis in general. However, the compound disaster that entailed earthquake, tsunami, and a nuclear crisis, along with disruption of the global supply chain triggered by the Great East Japan Earthquake in 2011, highlighted the need for a holistic risk assessment of impacts amplified by multiple disasters. According to the Cabinet Office of Japan, the occurrence probability of a Nankai Trough Earthquake and Tsunami is $70 \%$ within the next 30 years. It suggests the need for comprehensive impact assessment to enhance the disaster risk reduction strategies of the region. This study conducts a tsunami impact assessment using quantitative analysis to identify vulnerable industries in Mie Prefecture, Japan, famous for tourism, valueadded sectors of aquaculture, food processing, and petroleum refining tanks situated in at-risk areas. To create a tsunami shock scenario, we apply a computable general equilibrium (CGE) model using an input-output table of the Mie Prefecture (2015 version) and geographic information system (GIS). The street-level business entity data enable us to incorporate with the disaster scenario to provide evidence-based damage estimates of capital and labor loss due to a tsunami. We present the simulation results of output change, price change, external trade, and welfare analysis and propose creating a vulnerability index (VI) for disaster impact. These quantified and visualized indicators would provide informative implications for ex-ante policymaking and risk financing to cope with fragile sectors effectively.
\end{abstract}

JEL: C68, Q54, N75

Keywords: Tsunami disaster, CGE, GIS, IO table, Mie, Japan

\footnotetext{
${ }^{1}$ Research Fellow, Ocean Policy Research Institute, The Sasakawa Peace Foundation

${ }^{2}$ Policy Researcher, Institute for Global Environmental Strategies

* Corresponding author Email: michael-huang@spf.or.jp
} 


\section{INTRODUCTION}

Natural disasters, such as typhoons, heavy rains, floods, and earthquakes, affect our daily lives; however, the tsunami is a disaster that stakeholders tend to overlook its impacts due to its low occurrence rate. The Asian tsunami struck in 2004 and conveyed important messages to coastal countries about the importance of tsunami awareness and preparedness. Despite the reconstruction work that included tsunami information dissemination of hazard maps and other structural countermeasures, the massive losses due to the Great East Japan Earthquake and Tsunami of 2011 again revealed the inadequacies and potential for more effective measures (Løvholt, Setiadi, Birkmann, et al., 2014). This event also highlighted the importance of significant price changes and disruption of the global supply chain (Cavallo et al., 2014). Therefore, estimation of disaster impact is desirable for making ex-ante disaster risk management plans and countermeasures.

This study uses the Mie Prefecture as a case study to estimate the potential economic impact of the Nankai Trough earthquake with a $70 \%$ probability of occurrence in the next 30 years. Mie is a prefecture with an estimated population of 1.77 million and an area of $5,774 \mathrm{~km}^{2}$, located mid-west of the mainland (Honshu) Japan. Its coastline facing the Sea of Japan is 1,140 $\mathrm{km}$ long and is the seventh longest coastline in Japan. Mie Prefecture is blessed with abundant marine resources and is known for its lobster and pearl farming, which is one of the main reasons for its flourishing as a tourist destination. On the other hand, Mie Prefecture's primary industry is manufacturing, a higher value-added industry, and it generates more employment when compared to the national average (METI 2014). The northern part of Mie belongs to the Chukyo Industrial Zone, one of three major industrial zones in Japan.

Due to its geographical features, the Mie Prefecture frequently experiences natural disasters, including typhoons and tsunamis. Typhoon Talas in 2011 caused extensive damage, including building collapse and 82 casualties. A major earthquake hit the prefecture in 1944, and several more occurred in the last few decades. Studies have predicted a tsunami at the height of $26 \mathrm{~m}$ in the coming decades (Shima City and Toba City; Cabinet Office of Japan 2012a). Studies have predicted that the risk of liquefaction is particularly high in the coastal areas of Ise Bay (DPCD 2014).

The prefectural capital city of Tsu is the administrative and cultural center of the Mie Prefecture, where many companies with cutting-edge technologies, medical centers, and hospitals are based. Tsu has prospered as a trading port since ancient times, and today, it is a seaside city with an urban area along the coast. The city is home to one of Japan's largest shipbuilding and heavy industry plants as well as electronic component factories. In addition to the city center, which has the second-largest number of offices (approximately $14 \%$ of the total amount in the prefecture (DSPD 2016)) in the Mie Prefecture, these functions of Tsu as the center of the oceanic economy are essential to the prefecture's socioeconomic activities. Therefore, the occurrence of natural disasters in Tsu would have a severe impact on the entire prefecture. 


\subsection{Review on disaster impact assessment}

For economic disaster impact analysis, there are several types of conventional economic models, such as Input-Output (IO), Social Accounting Matrix (SAM), and Computable General Equilibrium (CGE) (Okuyama 2008).

An IO table can provide an overview of the economic structure and sectoral interdependence in the disaster scenario setting stage. Moreover, it can also help distinguish between economic losses triggered by labor and capital production factors (Okuyama and Chang 2004). The logic of IO analysis has been widely recognized to provide a timely estimate of the interconnected impact for recovery plans and finances to evaluate disaster countermeasures in the pre-event period (Okuyama and Santos 2014). Nevertheless, the limitation of IO analysis is its feature of linear analysis, identical and fixed products, and efficient employment of all local resources. The county-level SAM could be used to estimate economic damage due to lifeline failures (Cole 1998).

To further reveal the change in production and price resulting from a disaster shock, the computable general equilibrium (CGE) model is widely used. For example, it has been used to assess economic losses from natural disasters in studies conducted by Boisvert (1992), Brookshire and McKee (1992), Rose and Guha (2004), and Rose and Liao (2005). Moreover, in the realistic sense, price change, factor losses in capital, and labor endowment triggered by disaster shock may require non-linear interpretation, such as the CGE model, to simultaneously capture the fluctuation. For disaster impact assessment, the usefulness of the CGE model serves to identify vulnerable sectors for potential disasters. Such a model could provide a theoretical basis to explain the linkages of an economy with indirect impacts due to production loss (Huang and Hosoe 2016, 2017).

The application of the Global Trade Analysis Project (GTAP) model (multiregional, multisectoral CGE modeling) is considered an effective tool to investigate the disaster impact on price change, external trade, and welfare change on a global scale (Huang and Masuda 2020; Huang, Tanaka, and Yoshioka forthcoming). The quantified economic impact could visualize sectoral vulnerability and advise about disaster reduction plans in an ex-ante manner.

Under the support of a quantitative approach like the CGE model, the spatial analysis could strengthen the analytical capability with plausible geographic parameters in the model scope (Kajitani and Tatano 2019). While the CGE model is mainly limited to a single region scope, the support of a geographic information system (GIS) can efficiently improve the accuracy of estimated impacts (Chen et al., 2011). Moreover, building and population data can provide essential information for factor change assumptions to allocate public facilities (Lwin and Murayama 2009). For example, for studies in Japan, Tanaka and Huang (2021) analyzed the tsunami risk of Hakodate City in the Hokkaido area using a dynamic CGE model based on a hazard map and census used to assess tsunami disaster impact. Their simulation results showed that fisheries and other ocean-related industries would be highly vulnerable and may not recover simply with the fiscal support of Hakodate. 
In addition to the abovementioned econometrics, the vulnerability index (VI) has been discussed through many perspectives, such as the climate vulnerability index through GIS hazard mapping (Yusuf and Francisco 2009; Peduzzi, Dao, Herold et al. 2009; Moench, Khan, MacClune et al. 2017), livelihood vulnerability index to identify administrative level with socioeconomic and biophysical datasets (Shah, Dulal, Johnson et al. 2013; Mainali and Pricope 2019), and flood vulnerability to estimate the sub-catchment effect (Balica and Wright 2010; Balica, Wright, and Van der Meulen 2012; Karmaoui and Balica 2019). These multidisciplinary approaches to measuring the VI imply quantitative implications for disaster risk management. For instance, the VI of economic impact, propagation length, and sector size demonstrates the usefulness of enabling policymakers to determine key sector prioritization post-disaster (Yu, Tan, Aviso, et al. 2014).

\subsection{Aims and analytical flow}

This study provides a systematic methodology framework to estimate disaster risk and its economic impact using an industry and welfare analysis. Through CGE modeling based on an IO table of the Mie Prefecture and GIS analysis, we expect to capture the spatial features of the industry with concrete policy implications for disaster risk reduction. Additionally, the sectoral economic impact and VI will be demonstrated as comprehensive indicators to interpret the level of vulnerability.

The study proceeds as follows - Section 2 explains data-used, sectoral classification from IO table, the model structure and scenario setting of CGE, and tsunami damage estimation by GIS; section 3 presents the simulation results and design of the VI; the concluding remarks in section 4 provide policy recommendations and prospects.

\section{METHOD}

\subsection{Data}

In order to merge geographical information of industries and IO table datasets, we applied various data. Table 1 summarizes the information used in the study. 
Table 1. Summary of data used

\begin{tabular}{|c|c|c|c|c|}
\hline Name of data & Source & Spatial scale & Year & Note. \\
\hline $\begin{array}{l}\text { Tsunami hazard } \\
\text { map }\end{array}$ & MLIT (2016) & $10 \mathrm{~m}$ & 2016 & \\
\hline $\begin{array}{l}\text { Office (capital) } \\
\text { geographical data }\end{array}$ & NSS Corporation Ltd. (2020) & $\begin{array}{l}\text { Longitude, } \\
\text { Latitude }\end{array}$ & 2020 & 155 sectors \\
\hline Labor endowment & $\begin{array}{l}\text { Statistics Bureau of Japan } \\
(2018)\end{array}$ & Street division & 2016 & 99 sectors \\
\hline Building types & MIC (2019) & City, town & 2019 & Table A.1 \\
\hline Damage definition & $\begin{array}{l}\text { CDMC(2003), Hokkaido } \\
\text { Disaster Risk Reduction } \\
\text { Information (2006) }\end{array}$ & Japan & $\begin{array}{l}2003 \\
2006\end{array}$ & $\begin{array}{l}\text { Applied in } \\
\text { Tanaka and } \\
\text { Huang (2021) }\end{array}$ \\
\hline Input-output table & DSPD (2020) & Prefecture & 2015 & 42 sectors \\
\hline
\end{tabular}

\subsection{Sectoral classification}

Table 2. Economic structure of Mie Prefecture (\%)

\begin{tabular}{clcc}
\hline Abbreviation & \multicolumn{1}{c}{ Sector } & Output share & Capital dependency \\
\hline AGR & Agriculture & 0.8 & 78.6 \\
FIS & Fishery & 0.3 & 57.6 \\
POA & Coal and petroleum & 8.1 & 91.0 \\
FOD & Food processing & 3.8 & 53.6 \\
WPP & Wood, paper, and printing & 1.7 & 39.0 \\
CHM & Chemical products & 9.7 & 49.2 \\
POT & Pottery & 1.1 & 47.5 \\
STL & Steel & 5.7 & 39.9 \\
MCH & Machinery & 5.1 & 39.2 \\
EEQ & Electronic equipment & 13.1 & 61.1 \\
TEQ & Transport equipment & 10.9 & 42.8 \\
MAN & Manufacturing & 1.0 & 26.8 \\
CON & Construction & 2.7 & 15.6 \\
ELY & Electricity and water & 3.0 & 65.4 \\
PUB & Public administration & 1.9 & 41.7 \\
COM & Commerce & 6.9 & 36.5 \\
FIN & Finance & 5.2 & 83.3 \\
TRS & Transportation & 2.9 & 31.8 \\
EDU & Education & 3.1 & 27.0 \\
MED & Medical service & 3.3 & 16.6 \\
REC & Recreation, restaurant, and hotel & 2.4 & 39.8 \\
SRV & Service & 7.3 & 48.4 \\
\hline
\end{tabular}

Source: Extracted by the authors based on Mie Prefecture 2015 IO table 
We categorized 22 new sectors aggregated from 42 sectors organized in the 2015 Mie Prefecture IO table. Table 2 demonstrates the new sectoral classifications with the display of output share and capital dependency sourced from the IO table. The output share shows that the output share of $1^{\text {st }}$ industry of agriculture (AGR) and fishery (FIS) was only $1.1 \%$. In contrast, electronic equipment (EEQ), transport equipment (TEQ), chemical products (CHM), and coal and petroleum (POA) are the most important sectors of the $2^{\text {nd }}$ industry in the Mie Prefecture, accounting for $41.8 \%$ of the total output. For the $3^{\text {rd }}$ industry, service (SRV), commerce (COM), and finance (FIN) sectors account for $19.3 \%$ of the total output.

\subsection{Computable general equilibrium (CGE) model}

\subsubsection{Model structure}

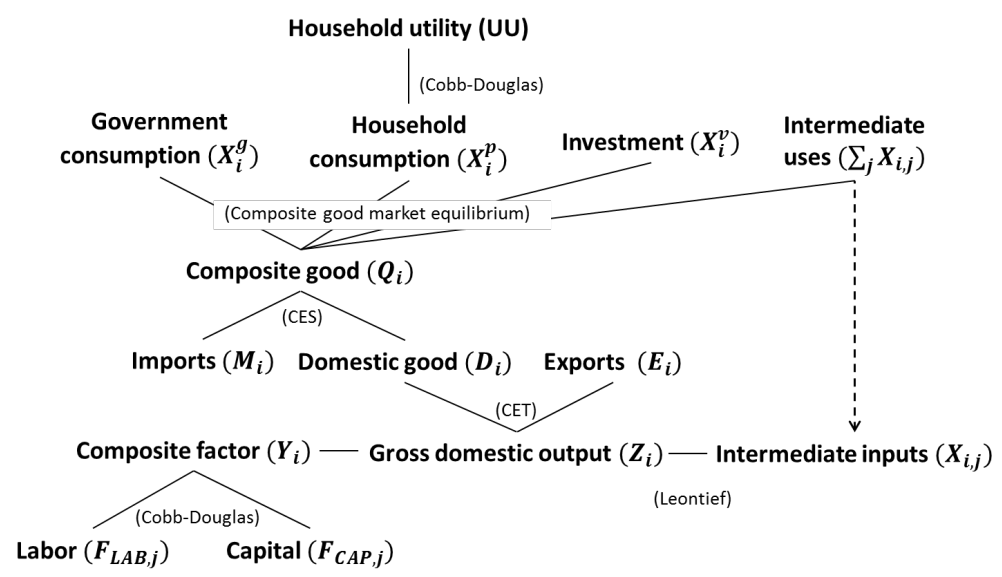

Figure 1. CGE model structure

Source: Amended by authors based on Hosoe et al. (2010) and Tanaka and Huang (2020).

To analyze the impact of tsunami disaster, we applied a CGE model to capture the economic impact triggered by an assumed tsunami shock. Based on the model structure developed by Hosoe, Gasawa, and Hashimoto (2010), we accommodated Mie's IO table with the disaster analysis methods initiated by Huang and Hosoe (2016). Figure 1 shows the model structure.

The production assumed a substitution between capital and labor factors in value-added production with Cobb-Douglas production functions. While the labor and capital input contributed to the sectoral output with the Leontief-type function as the production function for gross output made up of value-added and intermediate inputs. On the other hand, household and government, investment, and intermediate uses with elasticities are under Armington's composite goods (Armington 1969) assumption, which was calibrated from the GTAP database version 10 . We conducted a sensitivity test to ensure the robustness of the simulation results, 
as shown in tables A3 and A4. The gross output was transformed into domestic goods and exports, with constant elasticity of transformation (CET) functions as follows:

- Gross domestic output transformation function: $Z_{i}=\theta_{i}\left(\xi e_{i} E_{i} \phi_{i}+\xi d_{i} D_{i}{ }^{\phi_{i}}\right)^{1 / \phi_{i}}$ where $Z_{i}$ : sectoral output; $\xi$ : share parameter; $E_{i}$ : export good; $D_{i}:$ domestic good; $e_{i,} d_{i}$ : share coefficient for transformation; $\phi_{i}=$ transformation elasticity parameter.

- Export supply function: $E_{i}=\left[\frac{\theta_{i}{ }^{\phi_{i} \xi e_{i}\left(1+\tau_{i}^{z}\right) p_{i}^{z}}}{p_{i}^{e}}\right]^{1 /\left(1-\phi_{i}\right)} Z_{i}$

- Domestic good demand function: $D_{i}=\left[\frac{\theta_{i} \phi_{i} \xi d_{i}\left(1+\tau_{i}^{z}\right) p_{i}^{z}}{p_{i}^{d}}\right]^{1 /\left(1-\phi_{i}\right)} Z_{i}$ where $\theta_{i}^{\phi_{i}}$ : scale parameter in Armington function; $p_{i}^{d}, p_{i}^{z}, p_{i}^{e}$ : the price of goods.

Composite goods were produced with domestic goods, and imports with constant elasticity of substitution (CES) functions as follows:

- Gross domestic output substitution function: $Q_{i}=\gamma_{i}\left(\delta m_{i} M_{i} \eta_{i}+\delta d_{i} D_{i}{ }^{\eta_{i}}\right)^{1 / \eta_{i}}$ where $Q_{i}$ : sectoral output; $\delta$ : share parameter; $M_{i}$ : import good; $D_{i}$ : domestic good; mi, di : share coefficient for substitution; $\eta \mathrm{i}=$ substitution elasticity parameter;

- Import demand function: $M_{i}=\left[\frac{\gamma_{i} \eta_{i} \delta m_{i} p_{i}^{q}}{\left(1+\tau_{i}^{m}\right) p_{i}^{m}}\right]^{1 /\left(1-\eta_{i}\right)} Q_{i}$

- Domestic good demand function: $D_{i}=\left[\frac{\gamma_{i} \eta_{i} \delta d_{i} p_{i}^{q}}{p_{i}^{d}}\right]^{1 /\left(1-\eta_{i}\right)} Q_{i}$ where $\gamma_{i} \eta_{i}$ : scale parameter in Armington function; $p_{i}^{d}, p_{i}^{q}, p_{i}^{e}$ : the price of goods.

We use a Cobb-Douglas-type utility function to analyze social welfare, measured by the Hicksian equivalent variations (EVs) based on a household's change in consumption. Welfare refers to the expenditure function that contributes to the utility of EVs before $U U^{0}$ and after $U U^{l}$ in response to a disaster shock with output and price changes. Finally, we assume the household to be in Cobb-Douglas utility function, which depends on the consumption goods composite.

- Household demand for goods: $X_{i}^{p}=\frac{\alpha_{i}}{p^{q}}\left(\sum_{h, j} p_{h, j}^{f} F F_{h, j}-S^{p}-T^{d}\right)$ where $p^{q}$ : price of Armington's goods, $p^{f}$ : factor price, $S^{p}$ : private savings, and $T^{d}$ is tax.

- The welfare function was determined by $\operatorname{ep}\left(p^{q}, U U\right)=\min _{X P}\left\{p^{q} \cdot \mid U U\left(X^{p}\right)=U U\right\}$

$$
E V=e p\left(p^{q}, U U^{1}\right)-e p\left(p^{q}, U U^{0}\right)
$$

where $\operatorname{ep}(\cdot)$ :expenditure function, $X^{p}$ : consumption vector, and $p^{q}$ :price vector.

$U U$ : utility level (given); $U U(\cdot)$ : utility function 
The impact of disasters on capital and labor losses may lead to decreased production and a price change, resulting in a new equilibrium in household welfare as a social benefit or cost. If the price of import goods is lower than domestic goods, consumption and production may alter accordingly.

\subsection{GIS analysis}

\subsubsection{Office (capital) points and labor endowments in the tsunami hazard map}

The direct impact of tsunami hazard is determined by the estimated inundation area and height of the tsunami. We calibrated tsunami height data with the report prepared by Cabinet Office (2012a, 2012b) modeling a Nankai Trough M9.1 Earthquake. The seven most serious tsunami fault models for the Mie Prefecture were selected, and the simulation results were overlapped to extract the highest tsunami height, which was applied to the tsunami hazard map. The height of the tsunami was categorized with seven quantiles $(\leq 0.3 \mathrm{~m} ; 0.3-2 \mathrm{~m} ; 2-5 \mathrm{~m} ; 5-10 \mathrm{~m}$; 10-20m; 20-50m; and $\geq 50 \mathrm{~m}$ ).

We used the Mie Prefecture telephone dictionary to develop detailed simulations. In total, 710,059 office points supplied the names of offices by more than 1,200 industries. The number of industries was firstly categorized as 155 to ensure the analytical capacity of the study. Figure 2 shows the spatial distribution of tsunami flooding height and office location around Tsu in the Mie Prefecture.

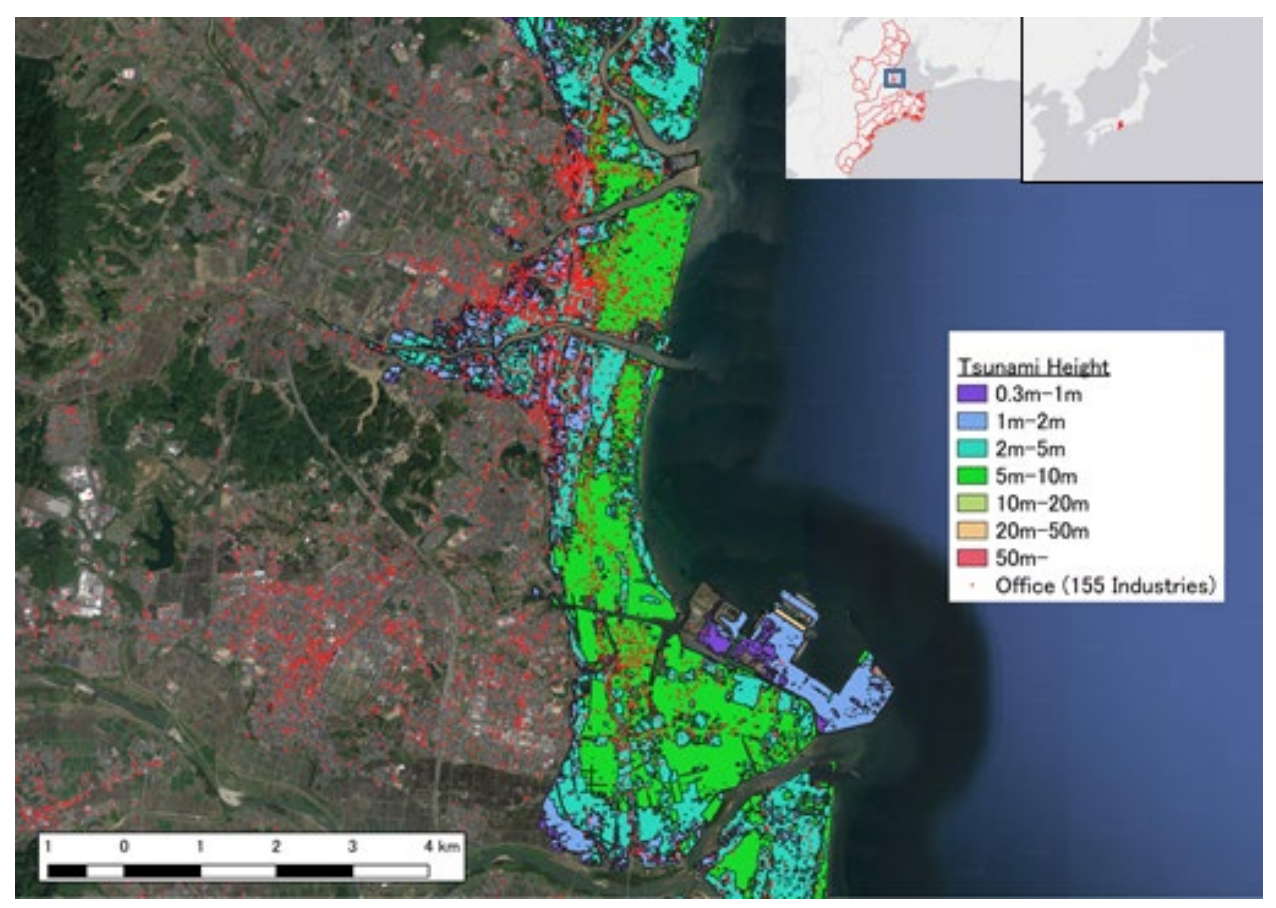

Figure 2. Tsunami-affected area and office (capital) points Source: Estimated by the authors. 
The office datasets have no information on labor; thus, it was assumed based on the Economic Census for Business Activity in 2016 with 99 industries and allocated to each office point based on the corresponding industrial classification. Merging 155 industries into 99 industries, we added the number of laborers in each industry at the street level to each point on the same street. Aggregating those 99 industries into sectoral classifications of Table 2, we consequently obtained geographical information of office points with the number of laborers from 22 industries and tsunami-height information.

\subsubsection{Tsunami damage estimation}

Damages caused by tsunamis generally differ based on the building material used and the structure. To accommodate this feature, we used city-level wooden/non-wooden ratio to estimate damage specifically, assuming that the homogenous ratio of wooden and non-wooden in each of the 29 sub-regions in the Mie Prefecture (Table A1). The damage definition for each building type followed the Central Disaster Management Council (CDMC) (2003) and Hokkaido Disaster Risk Reduction Information (2006), which distinguishes four damage categories: fully destroyed, half-destroyed, inundated over, and under floors with tsunami heights of $0.5 \mathrm{~m}$ or $1 \mathrm{~m}$ degree. However, the tsunami height published by the Mie Prefecture was categorized into seven quantiles, as mentioned above. Thus, the damage definition used in this study was not the same as that of the CDMC (2003) and Hokkaido Disaster Risk Reduction Information (2006). Table 3 lists the tsunami damage classifications.

Table 3. Tsunami damage definition

\begin{tabular}{ccc}
\hline \multirow{2}{*}{ Damage category } & \multicolumn{2}{c}{ Flooded height (m) } \\
\cline { 2 - 3 } & Wooden buildings & Non-wooden buildings \\
\hline $0 \%$ & $0.0 \mathrm{~m}<\mathrm{H}<0.3 \mathrm{~m}$ & $0.0 \mathrm{~m}<\mathrm{H}<2.0 \mathrm{~m}$ \\
$25 \%$ & $0.3 \mathrm{~m} \leqq \mathrm{H} \leqq 1.0 \mathrm{~m}$ & $2.0 \mathrm{~m} \leqq \mathrm{H}<5.0 \mathrm{~m}$ \\
$50 \%$ & $1.0 \mathrm{~m} \leqq \mathrm{H} \leqq 2.0 \mathrm{~m}$ & $5.0 \mathrm{~m} \leqq \mathrm{H}<10.0 \mathrm{~m}$ \\
$100 \%$ & $2.0 \mathrm{~m} \leqq \mathrm{H}$ & $10.0 \mathrm{~m} \leqq \mathrm{H}$ \\
\hline
\end{tabular}

Table 4 summarizes the results of the damage estimates. The estimated tsunami risk was highly associated with the location and building type. The sectors of the fishery (FIS), food processing (FOD), electricity and water (ELY), and transport equipment (TEQ) revealed the most severe damage of $14.9 \%-51.4 \%$, while the total labor loss rate was $8.1 \%$. 
Table 4. Sectoral damage estimate

\begin{tabular}{ccccc}
\hline Sector & $\begin{array}{c}\text { Damaged } \\
\text { wooden building }\end{array}$ & $\begin{array}{c}\text { Damaged non- } \\
\text { wooden building }\end{array}$ & Total building & Sector damage \\
\hline AGR & 23 & 5 & 545 & $7.3 \%$ \\
FIS & 38 & 7 & 124 & $51.4 \%$ \\
POA & 5 & 1 & 73 & $12.2 \%$ \\
FOD & 135 & 26 & 1,171 & $14.9 \%$ \\
WPP & 99 & 18 & 1,536 & $11.6 \%$ \\
CHM & 29 & 5 & 663 & $8.9 \%$ \\
POT & 27 & 5 & 561 & $4.8 \%$ \\
STL & 90 & 20 & 1,169 & $13.9 \%$ \\
MCH & 66 & 14 & 992 & $10.9 \%$ \\
EEQ & 37 & 8 & 505 & $13.5 \%$ \\
TEQ & 46 & 10 & 541 & $14.7 \%$ \\
MAN & 30 & 6 & 431 & $12.2 \%$ \\
CON & 536 & 100 & 7,878 & $11.6 \%$ \\
ELY & 11 & 2 & 106 & $19.2 \%$ \\
PUB & 141 & 26 & 1,416 & $11.4 \%$ \\
EDU & 152 & 27 & 2,544 & $7.9 \%$ \\
COM & 1,651 & 305 & 19,562 & $14.1 \%$ \\
FIN & 427 & 77 & 5,104 & $11.7 \%$ \\
TRS & 175 & 31 & 2,340 & $12.5 \%$ \\
MED & 371 & 67 & 5,646 & $10.2 \%$ \\
REC & 1,300 & 234 & 15,358 & $13.9 \%$ \\
SRV & 634 & 112 & 8,841 & $11.2 \%$ \\
LAB & 49,559 & 9,120 & 726,863 & $8.1 \%$ \\
\hline
\end{tabular}

\section{SIMULATION RESULTS}

\subsection{Tsunami risk scenario}

Based on the estimated damage shown in Table 4, we employed the CGE model with the aggregated 22-sector IO table. The capital and labor damage rates were calibrated into capital stock and labor endowment to reduce production factors. Meanwhile, to adequately demonstrate the sectoral losses resulting from tsunami damage and the actual situation of labor mobility, the capital was assumed to be immobile within a certain sector. In contrast, the labor factor was assumed to be mobile and could flow between sectors. Thus, the scenario setting could demonstrate the shock caused by a tsunami, its consequences for sectoral production, and the subsequent effect on prices and welfare.

After the tsunami shock in the scenario, the static simulation results of one period showed a change in economic indicators, including output, price, and external trade (Table 5). Thus, the impact was a one-year consequence, indicating the consequences of reducing production 
factors (capital and labor). The following subsection will interpret the results in detail and propose the design of the VI.

Table 5. Simulation results of tsunami shock (\%)

\begin{tabular}{ccccc}
\hline Sector & Output & Price & Export & Import \\
\hline AGR & -7.3 & 0.7 & -4.4 & -13.5 \\
FIS & -39.8 & 20.8 & -51.3 & -4.6 \\
POA & -12.1 & 2.0 & -12.2 & -11.4 \\
FOD & -15.3 & 2.2 & -15.8 & -10.7 \\
WPP & -9.3 & 1.9 & -9.3 & -9.5 \\
CHM & -7.6 & 1.8 & -7.3 & -9.0 \\
POT & -4.2 & 1.5 & -3.0 & -10.3 \\
STL & -11.7 & 2.0 & -11.9 & -10.4 \\
MCH & -8.4 & 2.0 & -8.7 & -6.8 \\
EEQ & -12.1 & 2.4 & -13.7 & -7.3 \\
TEQ & -12.4 & 2.2 & -13.0 & -10.1 \\
MAN & -10.0 & 1.9 & -9.8 & -10.4 \\
CON & -6.3 & 1.6 & -5.6 & -6.9 \\
ELY & -15.8 & 5.0 & -22.6 & -3.6 \\
PUB & -9.8 & 1.6 & -9.2 & -10.6 \\
COM & -6.5 & 1.3 & -5.4 & -10.4 \\
FIN & -13.1 & 5.5 & -18.5 & -6.8 \\
TRS & -9.3 & 1.6 & -8.7 & -10.4 \\
EDU & -8.0 & 2.0 & -8.1 & -7.8 \\
MED & -9.3 & 0.9 & -7.5 & -11.0 \\
REC & -10.6 & 2.4 & -11.4 & -9.6 \\
SRV & -9.6 & 1.8 & -9.4 & -9.9 \\
EV & & $-496,756$ million JPY & \\
\hline
\end{tabular}

\subsection{Output change}

Due to the geographic features of the coastal area, the high exposure to tsunami risk of fisheries (FIS) was foreseeable. The output of the FIS decreased by $39.8 \%$, followed by the sectors of electricity and water (ELY) (-15.8\%), food processing (FOD) (-15.3\%), finance (FIN) (13.1\%), transport equipment (TEQ) (12.4\%), electronic equipment (EEQ) (-12.1\%), coa and petroleum (POA) (-12.1\%), steel (STL) (-11.7\%), while other manufacturing sectors showed a $4 \%-10 \%$ decrease. The impact was considerably high in the abovementioned industries in the Mie Prefecture.

\subsection{Price change}

The price indicator in the CGE model structure does not directly relate to the market price. Rather, it is a consequence of the new equilibrium of demand and supply. Nevertheless, the 
price indicator can help interpret the indirect impact of follow-up market transaction activities. Due to the massive output decrease in fisheries (FIS), the price increased substantially by $20.8 \%$, implying the scarcity of production and reduced competitiveness in the export market (to other regions). Other notable changes are in electricity (ELY), finance (FIN) by $5 \%$. The price change in different sectors showed a slight increase of $1 \%-2 \%$, showing that the economic structure fluctuated accordingly.

\subsection{External trades}

The impact on sectoral exports showed a similar trend and decreased the rate with the output change, except that the fishery (FIS) showed a more significant decrease in exports by $51.3 \%$. As for imports in other manufacturing sectors, agriculture (AGR), wood, paper, and printing (WPP), machinery (MCH), and pottery (POT) showed lower rates than their exports, implying that facility damage also reduced the demand for intermediate inputs.

\subsection{Welfare analysis}

Social welfare was measured using Hicksian Equilavent Variations (EV) based on the household consumption change according to the consumption composite ratio and income. Based on the simulation results, as all sectoral prices increased, the reduction of production generated resulted in a significant decrease in social welfare. Compared to the pre-disaster situation, the EV showed a decline of JPY496,756 million, equivalent to JPY668,049 for each household in the Mie Prefecture. ${ }^{3}$

\subsection{Vulnerability index}

In addition to the simulation results from the static CGE model analysis, we propose VI as an indicator that could help identify vulnerable sectors in the present situation. The purpose of the index is to provide an instant and visualized indicator to raise awareness for sectors where the vulnerability could be underestimated or overlooked within the indirect disaster impact, such as output or price change. When vital sectors in the second industry, such as electronic equipment (EEQ), transport equipment (TEQ), chemical products (CHM), and petroleum (POA), are more capable of implementing structural measures for disaster risk reduction, such as location and building reinforcement, small-medium enterprises (SMEs) may not be able to detect such risks. Their vulnerability remains hidden in the location of business units.

The design of the VI is set with the purpose of identifying the correlation between the disaster impact and the tsunami damage on the capital factor, highlighting sectors with less capital loss

\footnotetext{
${ }^{3}$ Based on the 2021 census, there are 743,592 households in the Mie Prefecture.
} 
but greater output loss. The formula can examine the ratio of disaster impact and capital damage to identify vulnerable sectors. The formula for VI was derived as follows:

$$
\text { Vulnerability Index }(V I)=\frac{\text { Disaster impact }}{\text { Capital damage }}
$$

where disaster impact: change of output, price, and external trade

VI may also represent the relative importance of a sector in contrast to other sectors in the economy. Following Yusuf and Francisco (2009), we normalized the index $\widetilde{V I}_{i}$ to the value between 0 and 1 .

$$
\widetilde{V I}_{i}=\frac{V I_{i}-V I_{i}^{M i n}}{V I_{i}^{M a x}-V I_{i}^{M i n}}
$$

where $i$ is the sectoral impact, $V I_{i}^{M a x}-V I_{i}^{M i n}$ is the interval of the index, and the interval could be reversed if $\mathrm{VI}_{i}$ is negative.

A higher unit represents higher vulnerability and a significant change. The visualization of the index could provide comprehensive information on the sectoral structures and serve as a good reference for stakeholders. Figure 3 shows the VIs of output, price, exports, and imports.

The output VI of agriculture (AGR), food processing (FOD), coal and petroleum (POA) were the highest among all sectors, followed by finance (FIN), medical service (MED), electronic equipment (EEQ), pottery (POT), public administration (PUB), service (SRV), chemicals (CHM). The VI for sectors in the second industry sector was relatively low, referring to their ex-ante countermeasures of location and building type. The sectors with a high VI implied that their exposed area and vulnerability could have been underestimated, and the disclosure of their fragility could be a reminder of a compound disaster risk because FOD, AGR, and POA should be the key sectors for disaster aftermath and reconstruction.

Price VI could be informative, especially for the sectors in the second industry, to adjust their strategy and ex-ante preparation for price fluctuations. The high price VI for fisheries (FIS), finance (FIN), pottery (POT), electricity (ELY) are quite significant, implying the scarcity of capital factor due to the sectoral damage and output decrease. In contrast, price VI of coal and petroleum (POA), food processing (FOD), wood, paper, and printing (WPP), and steel (STL) remained relatively low, indicating their resilience while facing the disaster. 
As for the external trade VI, we mainly focus on the second industry. The export of food processing (FOD), electronic equipment (EEQ), fisheries (FIS), coal and petroleum (POA) are more affected by the decrease in output. On the other hand, the high import VI in agriculture (AGR) and pottery (POT) indicated the decrease of aggregate demand.

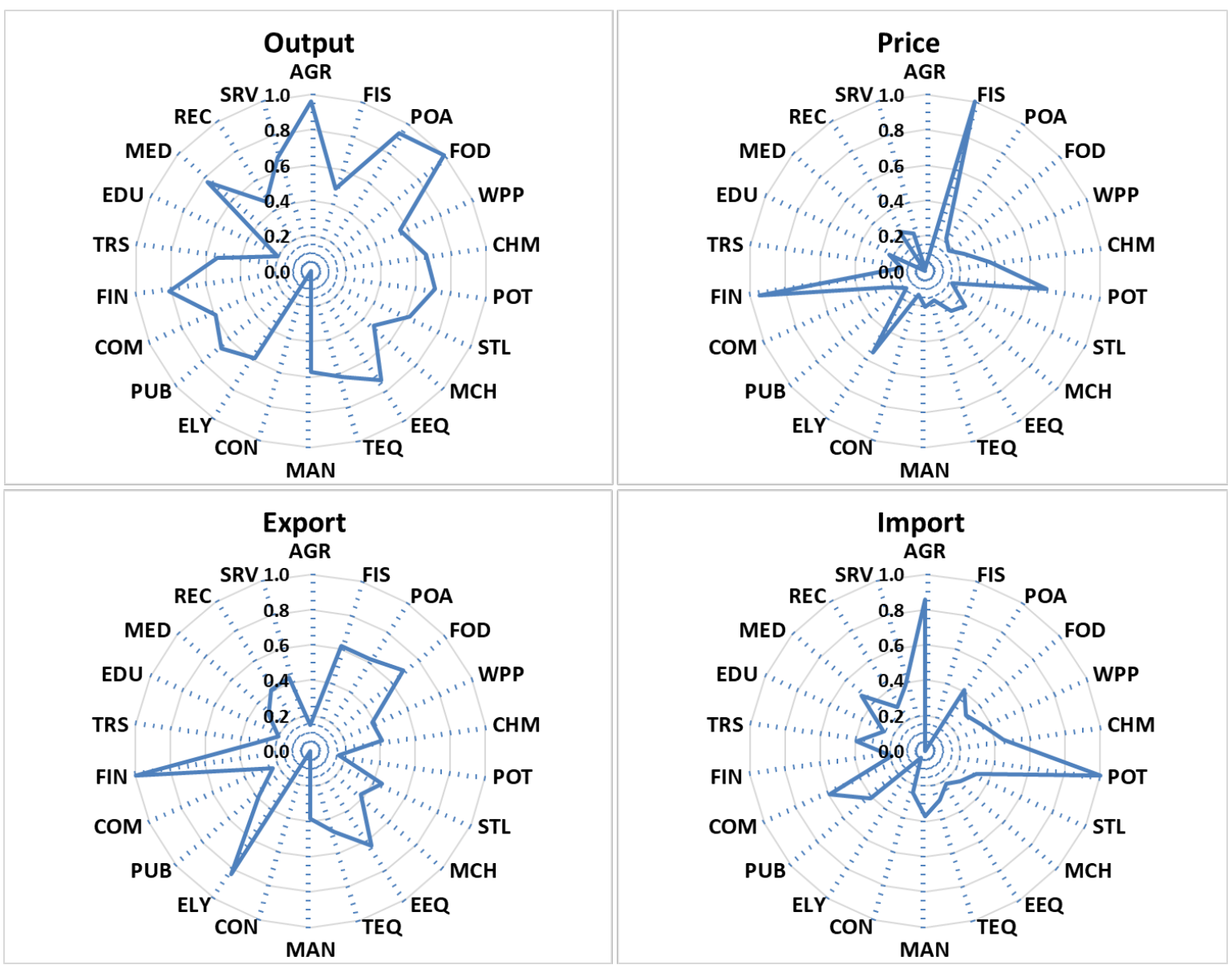

Figure 3. Vulnerability index of the impact

\section{CONCLUSIONS AND POLICY IMPLICATION}

This study provides a systematic and analytical methodology flow on disaster impact estimates of a possible Nankai Trough Earthquake and Tsunami in the Mie Prefecture of Japan by applying a CGE model and GIS.

The simulation results showed that the output of several sectors in the second industry could decrease significantly, such as electronic equipment (EEQ), transport equipment (TEQ), steel (STL), and commerce (COM), which could be reduced by $10 \%-15 \%$. In comparison, their price fluctuates by $2 \%-3 \%$. Additionally, fisheries (FIS) are drastically damaged in most 
indicators. The regional "vassal and harbor support mechanisms" should be developed to increase the capacity for disaster preparedness.

While the direct impact of a tsunami disaster could be interpreted in the form of capital and labor losses, we further proposed the creation of VI to further investigate the correlation between disaster impact and capital damage. Such indicators could help identify the indirect impact underestimated and overlooked, which could be informative for small and medium enterprises. VI can serve as an informative instrument for holistic risk identification. The highest output VI was revealed in food processing (FOD), agriculture (AGR), coal, and petroleum (POA), implying increased exposure in location and vulnerability to building type. Therefore, stakeholders should consider more ex-ante countermeasures, such as building reinforcement, relocation, or risk pooling through another insurance instrument to increase resilience.

This study has several limitations. Despite disaster impact and vulnerability assessment, the assumption of building categories of each capital may have been oversimplified at the city level. At the same time, the sector classification in the IO table, census, and GIS database was not specific or updated enough to enable more in-depth analysis. Meanwhile, interference between other regions in Japan was not considered, and an inter-regional analysis may be necessary. Nevertheless, this has been the most updated, accurate, and timely dataset that we could obtain.

As a future study, it would be more interesting to design a scenario of compound disasters for other cascading disasters, such as pandemics and energy crises, if the datasets permit. A dynamic analysis is desirable for follow-up research to estimate the recovery path and fund requirements for developing more financing instruments, enabling stakeholders to make costeffective resource allocations for resilience investment.

We examine the impact of a tsunami on industries in Mie Prefecture by combining geographic information data and the CGE model. Our quantitative analysis provides insights for ex-ante disaster preparedness and risk mitigation investment by identifying vulnerable sectors in a region. The damage estimate enabled us to establish an evidence-based tsunami scenario with a comprehensive spatial analysis of the sectoral impact. The quantified and visualized disaster assessment would help researchers and stakeholders capture the economic impacts from the scope of sectoral vulnerability.

\section{REFERENCES}

Armington, P. (1969) A Theory of demand for products distinguished by place of production. IMF Economic Review 16: 159-178.

Balica, S., and Wright, N. (2010) Reducing the complexity of the flood vulnerability index. Environmental Hazards 9(4): 321-339.

Balica, S., Wright, N., and van der Meulen, F. (2012). A flood vulnerability index for coastal cities and its use in assessing climate change impacts. Natural Hazards 64: 73-105. 
Boisvert, S. (1992) Indirect losses from a catastrophic earthquake and local, regional, and national interest. In: Indirect Economic Consequences of a Catastrophic Earthquake, Washington, DC: National Earthquake Hazards Reduction Program, Federal Emergency Management Agency, 207-265.

Brookshire, D. and Mckee, M. (1992) Other indirect costs and losses from earthquakes: issues and estimation. In: Indirect Economic Consequences of a Catastrophic Earthquake, Washington, DC: National Earthquake Hazards Reduction Program, Federal Emergency Management Agency, 267-325.

Cabinet Office. (2012a) 南海トラフ巨大地震対策検討ワーキンググループ報道発表資料 一式（平成 24 年 8 月 29 日発表）資料 $1-2$ 都府県別市町村別最大津波高一 覧表 $<$ 満潮位 $>$ [Nankai Trough Earthquake Countermeasures Working Group Press Release (August 29, 2012), Document 1-2 Maximum Tsunami Height by City, Town and Village by Prefecture $<$ High Tide Level $>$ ] (in Japanese).

Cabinet Office. (2012b) 南海トラフ巨大地震対策検討ワーキンググループ報道発表資 料一式（平成 24 年 8 月 29 日発表）資料 $1-3$ 市町村別平均津波高一覧表 $<$ 満潮位 $>$ [The Nankai Trough Earthquake Countermeasures Working Group Press Release (released on August 29, 2012), Document 1-3: List of Average Tsunami Height by Municipality $<$ High Tide Level $>$ ] (in Japanese).

Cavallo, A., Cavallo, E., and Rigobon, R. (2014) Prices and supply disruptions during natural disasters. Review of Income and Wealth 60(52): 449-471.

Central Disaster Management Council (CDMC). (2003) 「東南海、南海地震等に関する専 門調査会」（第 14 回）東南海・南海地震防災対策推進地域の指定基準につい $\tau$ [Special Investigation Committee on Tonankai and Nankai Earthquakes (14th), Designation criteria for Tonankai / Nankai earthquake disaster prevention measures promotion area] (in Japanese).

Chen, A., Peña-Mora, F. and Ouyang, Y. (2011) A collaborative GIS framework to support equipment distribution for civil engineering disaster response operations. Automation in Construction 5(20): 637-648.

Cole, S. (1998) Decision support for calamity preparedness: socioeconomic and interregional impacts, in: M. Shinozuka, A. Rose and R.T. Eguchi (Eds) Engineering and Socioeconomic Impacts of Earthquakes, NY: Multidisciplinary Center for Earthquake Engineering Research, 125-153.

Flanagan, B., Gregory, E., Hallisey, E., Heitgerd, J., and Lewis, B. (2020) A social Vulnerability index for disaster management. Journal of Homeland Security and Emergency Management 8(1).

Hokkaido Disaster Risk Reduction Information. (2006) 報告書データ (平成 18 年度 津波 シミュレーション及び被害想定調查業務 太平洋沿岸西部) [Data of Report (Tsunami simulation and research of expected damage Western Pacific coast in 2006)] (in Japanese).

Hosoe, N., Gasawa, K., and Hashimoto, H. (2010) Textbook of Computable general Equilibrium Modeling: Programming and Simulations. Basingstoke: Palgrave Macmillan.

Huang, M., and Hosoe, N. (2016) Computable general equilibrium assessment of a compound disaster in northern Taiwan. Review of Urban \& Regional Development Studies 28(2): 89106. 
Huang, M., and Hosoe, N. (2017) Fiscal and social costs of recovery programs for an earthquake disaster in northern Taiwan. Journal of Asian Economics 53: 1-17.

Huang, M., and Masuda, A. (2020) How do production networks affect the resilience of firms to economic and natural disasters: A methodological approach and assessment in Japan, Taiwan and Thailand. In: Anbumozhi V., Kimura F., Thangavelu S. (eds) Supply Chain Resilience. Springer.

Kajitani, Y., and Tatano, H. (2019) Advantages of the regional and sectoral disaggregation of a spatial computable general equilibrium model for the economic impact analysis of natural disasters. In Okuyama Y., Rose A. (eds) Advances in Spatial and Economic Modeling of Disaster Impacts, pp 327-358. Springer.

Karmaoui, A. and Balica, S. (2021) A new flood vulnerability index adapted for the preSaharan region, International Journal of River Basin Management 19(1): 93-107.

Løvholt, F., Setiadi, N., Birkmann, J., Harbitz, C., Bach, C., Fernando, N., Kaiser, G., and Nadim, F. (2014) Tsunami risk reduction - are we better prepared today than in 2004 ? International Journal of Disaster Risk Reduction 10: 127-142.

Lwin, K., and Murayama, Y. (2009) A GIS approach to estimation of building population for micro-spatial analysis. Transactions in GIS 13(4): 401-414.

Mainali, J. and Pricope, N. (2019) Mapping the need for adaptation: assessing drought vulnerability using the livelihood vulnerability index approach in a mid-hill region of Nepal, Climate and Development 11(7): 607-622.

Moench, M., Khan, F., MacClune, K.,Amman, C., Tran, P., Hawley, K. (2017) Transforming vulnerability: shelter, adaptation, and climate thresholds, Climate and Development 9(1): 22-35.

Mie Prefectural Government's Disaster Prevention and Countermeasures Department (DPCD). (2014) 地震被害想定調査結果（リスク関係）の概要について [The results of the earthquake damage estimation survey (hazard-related) Overview](in Japanese).

Mie Prefectural Government's Statistics Division, Strategic Planning Department (DSPD). (2016) 平成 26 年経済センサス [Results of the 2016 Economic Census] (in Japanese).

Mie Prefectural Government's Statistics Division, Strategic Planning Department (DSPD). (2020) 平成 27 年三重県産業連関表 [Input-Output table of Mie Prefecture in 2015] (in Japanese).

Mie Prefectural Government's Disaster Prevention Measures Department (DPMD). (2015) 津 波浸水予測図（平成 25 年度地震被害想定調査） [The tsunami inundation expectation area map (Research of expected of damage by earthquake in 2015)] (in Japanese).

Ministry of Economy, Trade and Industry (METI). (2014) 三重県の地域経済分析 [Regional Economic Analysis of Mie Prefecture] (in Japanese).

Ministry of Internal Affairs and Communications (MIC). (2019) 令和元年度（平成 31 年 度） 固定資産の価格等の概要調書 [Outline report of price etc. of fixed assets] (in Japanese).

Ministry of Land, Infrastructure, Transport and Tourism (MLIT). (2016) Tsunami Inundation simulation data. 
NSS Corporation Ltd. (2020) 全国事業所データベース [Database of nationwide offices] (in Japanese).

Okuyama, Y., and Chang, S. (2004) Modeling Spatial and Economic Impacts of Disasters, Springer.

Okuyama, Y. (2008) Critical review of methodologies on disaster impact estimation, Background paper for EDRR report.

Okuyama,Y. and Santos, J. (2014) Disaster impact and input-output analysis, Economic Systems Research 26(1): 1-12.

Peduzzi, P., Dao, H., Herold, C., and Mouton, F. (2009) Assessing global exposure and vulnerability towards natural hazards: The Disaster Risk Index. Natural Hazards and Earth System Science 9: 1149-1159.

Rose, A., and Guha, G. (2004) Computable general equilibrium modeling of electric utility lifeline losses from earthquakes. In: Modeling Spatial and Economic Impacts of Disasters, Berlin: Springer, 119-141.

Rose, A., and Liao, S. (2005) Modeling Regional Economic Resilience to Disasters: A Computable General Equilibrium Analysis of Water Service Disruptions. Journal of Regional Science 45(1): 75-112.

Statistics Bureau of Japan. (2018) 2016 Economic Census for Business Activity.

Tanaka, H., and Huang, M. (2021) Impact assessment and a fiscal recovery policy for tsunami risk: GIS and the general equilibrium approach in Hakodate city, Japan. Environment and Planning B: Urban Analytics and City Science 48(5):1144-1160. https://doi.org/10.1177/2399808320977865

Yu, K., Tan, R., Aviso, K., Promentilla, M. and Santos, J. (2014) A Vulnerability index for post-disaster key sector prioritization, Economic Systems Research 26(1): 81-97.

Yusuf, A., and Francisco, H. (2009) Climate change vulnerability mapping for Southeast Asia vulnerability, Economy and Environment Program for Southeast Asia (EEPSEA) https://www.preventionweb.net/files/7865 12324196651MappingReport1.pdf 